\title{
A Study of Influences of Endowment Effect upon Peasant Household's Farmland Transfer Willingness in the Perspective of Property Rights Economics
}

\author{
Houceng \\ Department of Business Management \\ Jilin Business and Technology College \\ Jilin Province, Changchun \\ 770696641@qq.com
}

\begin{abstract}
The correlation between endowment effect and peasant household's farmland transfer willingness is revealed through empirical analysis based on theoretical researches. The researches show that endowment effect is an important influence factor of peasant household's farmland transfer willingness; meanwhile, the stronger the active ability of property rights is, the clearer the boundary of property rights is, the more serious peasant's reigning disposition circumstances are, and the stronger endowment effect is.
\end{abstract}

Keywords-Endowment Effect; Strength of Property Rights; Farmland Transfer Willingness

\section{INTRODUCTION}

In order to enable agricultural economy to adapt to the development of modern economic society better, farmland transfer has become an inevitable choice for preventing the act of abandoning farmland and optimizing the distribution of agricultural resources. In China, peasants, as the subject of farmland transfer, have always regarded land as "the root of life”, and the man-land relationship is both close and cruel, which determines land's dual functions for peasants, production function and guarantee function.

Based on the special "relationship between peasant and land” arising from China's special national conditions, there are special farmland systems and special farmer behaviors; in other words, peasants are confronted with few farmland recourses, the top rational principle is the security of survival and the foremost decision-making foundation is not economic rationality but survival ethics (Scott, 1976)[3].

Based on theories of endowment effect, the author discusses peasant household's farmland transfer willingness in the perspective of the strength of property rights economics with the view to deepen peasant household's awareness of farmland transfer mechanism and to the scientific process of farmland transfer in China.

\section{Proposal of Endowment EFFECT AND Property RightS STRENGTH}

\section{A. Endowment Effect}

According to Radin's viewpoint (1982)[1, 2], when an individual possesses something (property) in a period of time to some extent, the thing (property) will be personalized by the individual to some extent. Regardless of the degree of personalization, losses thus incurred will cause large or small damage to the individual, namely pain. In case that such pain can be relieved and even eliminated by a substitute, the substituent thing (property) is a replaceable property; in case that such pain cannot be replaced, the thing (property) is endowed with a special meaning by the owner and thus called personal property.

Endowment effect refers to endow an individual possessing something with a special meaning and thus enables the thing to be a part of the individual. It prefers to appreciate highly of the thing than to suffer the pain of losing it. The higher the subjective value of a personal property with a higher financial condition or a stronger degree is, the stronger endowment effect is.

\section{B. Property Rights Strength}

An ideal hypothesis of zero transaction cost is raised by neoclassical economics, by which decision makers can acquire information needed at all costs (time, energy or money). As a matter of fact, transaction cost cannot be zero, it is an important even a decisive factor to be considered during the transaction process. [5]

With transaction cost, people must fully define the property right before carrying out rational market transactions so as to avoid conflicts and unnecessary cost escalation arising from scrambling for scarce resources. Thus, Alchian indicated that "all pricing problems are matters concerned with property right”. Value judgment of articles possessed by the property right owner during the transaction process is fundamentally determined by the size of property right to be transacted, 
namely the "strength" of property right to be transacted (Zhong Wenjing, Luo Biliang, 2013). [4]

\section{Relationship between Property Rights Strength and Resource Endowment}

1) Transaction of property rights is determined by both law and the strength of endowment effect

When peasants intend to transact a strong personal article (such as a piece of land), they consider not only legal restraints or to obtain material interests but also the degree of social recognition, namely social and moral support which mainly depends on people's self-conscious choice of ethics and truths. Fairness of such choice is the basis for transactions of property rights; property right owner will consider transactions of property rights to result in unnecessary losses but for such fairness and thus inevitably choose continuous possession and finally prevent value loss. Therefore, nontransaction is the cost-optimal transaction under a stronger endowment effect, and peasant household's farmland transfer willingness will inevitably be confined.

2) In case that property rights obtain both legal recognition and social recognition, the endowment effect is particularly strong

Legal and social recognition intensifies exclusive consciousness of the property right owner and the willingness of continuous possession, but weakens the willingness of transaction. In particular, the article and the owner are integrated and the transaction of real right changes to a right transaction combining the article and the owner in case that the article of dual recognition is the survival source of the owner, as a result, strong endowment effect and unfulfilled transaction will largely restrain peasant household's farmland transfer willingness.

3) In case that property right owner considers the article possessed to be the baseline of survival and has full control of the article possessed, and transactions and consequences are irreversible, the endowment effect should be very strong.

Substantially, farmland transfer means to transact the right of management with the contracting right reserved, which indicates that peasants will lose the actual control power of land and cannot foresee potential usage and quality of land; peasants will not be able to bear irreversible risks of such uncertainty, if any. Thus, the endowment effect is extremely strong and peasant household's farmland transfer willingness will be largely restricted.

\section{Proposal AND Demonstration OF TheORETICAL HYPOTHESIS}

Hypothesis 1: peasant households not participating in farmland transfer have stronger endowment effect but weaker farmland transfer willingness than those participating in farmland transfer.

Hypothesis 2:identification of rural cadres will affect peasant household' strength of property rights and result in different endowment effects, as a result, peasant household's farmland transfer willingness will cause different influences.
Hypothesis 3: different active abilities of peasant households will cause different endowment effect and thus pose different impacts upon peasant household's farmland transfer willingness.

\section{A. Sample Description}

The author visited 50 land contractors of Jilin Province in 2014, issued 500 questionnaires and collected 478 with a recovery rate of $95.6 \%$. Basic information of samples are shown below.

TABLE I. SAMPLE BASIC INFORMATION

\begin{tabular}{|l|l|l|}
\hline & $\begin{array}{l}\text { Peasant Households } \\
\text { Participating in Farmland } \\
\text { Transfer }\end{array}$ & $\begin{array}{l}\text { Peasant Households } \\
\text { not Participating in } \\
\text { Farmland Transfer }\end{array}$ \\
\hline Ratio & 54 & 46 \\
\hline $\begin{array}{l}\text { Farm population } \\
\text { ratio }\end{array}$ & 45 & 59 \\
\hline $\begin{array}{l}\text { Agricultural } \\
\text { income ratio }\end{array}$ & 42 & 53 \\
\hline $\begin{array}{l}\text { Contract area per } \\
\text { capita (ha.) }\end{array}$ & 0.16 & 0.13 \\
\hline
\end{tabular}

As shown in Table 1, peasant households not participating in farmland transfer are mainly engaged in agriculture, the farm population ratio is $14 \%$ higher than that of peasant households participating in farmland transfer; agricultural income is the main economic source of peasant households not participating in farmland transfer with a ratio of $9 \%$ higher than that of peasant households participating in farmland transfer, the farmland area contracted per capita of peasant households not participating in farmland transfer is smaller.

\section{B. Analysis of Connected Factors}

1) Extraction of evaluation indexes

The relationship between endowment effect and peasant household's farmland transfer willingness is analyzed from the point of executing ability of property rights, resource endowment of peasant households and strength of peasant household's property rights. ability

a) Main evaluation indexes of property rights executive

Executing ability of property rights is mainly reflected in two aspects: confined to incompleteness of knowledge and legal costs, real delimitation of property rights is always incomplete, and thus residual right exists beyond legal definition; besides, the stronger side has stronger ability to perform property rights due to non-rationality and pursuit of interests of two trading parties during the transaction process, even though property rights are fully defined. In this paper, executing ability of property rights is mainly measured as follows: (Table 2 Property rights executive ability evaluation indexes) 
TABLE II. PROPERTY RIGHTS EXECUTIVE ABILITY EVALUATION INDEXES

\begin{tabular}{|l|l|l|l|}
\hline Index & State & Data Reduction \\
\cline { 3 - 4 } & Sample Number & Ratio (\%) \\
\hline $\begin{array}{l}\text { Farmland } \\
\text { transfer } \\
\text { peasant } \\
\text { household? }\end{array}$ & Yes & 258 & 54 \\
\cline { 2 - 4 } $\begin{array}{l}\text { Purpose of } \\
\text { farmland } \\
\text { possession }\end{array}$ & Self-use & 335 & 46 \\
\hline $\begin{array}{l}\text { Land } \\
\text { abandoning }\end{array}$ & Sale & 143 & 70 \\
\cline { 2 - 4 } & No & 76 & 30 \\
\hline
\end{tabular}

b) Peasant household resource endowment evaluation indexes

Peasant household's endowment effect means that peasant households that possess land will endow land with a special meaning and enable it to be personal property. They prefer to appreciate highly of the land than to suffer the pain of losing it. Detailed evaluation indexes are shown in Table 3.

TABLE III. PEASANT HOUSEHOLD RESOURCE ENDOWMENT EVALUATION INDEXES

\begin{tabular}{|c|c|c|c|}
\hline Index & State & $\begin{array}{l}\text { Sample } \\
\text { Number }\end{array}$ & Ratio (\%) \\
\hline \multirow[t]{2}{*}{$\begin{array}{l}\text { Agricultural } \\
\text { income ratio }\end{array}$} & $\begin{array}{l}\text { Peasant households } \\
\text { participating in farmland } \\
\text { transfer }\end{array}$ & 201 & 42 \\
\hline & $\begin{array}{l}\text { Peasant households not } \\
\text { participating in farmland } \\
\text { transfer }\end{array}$ & 277 & 53 \\
\hline \multirow[t]{2}{*}{$\begin{array}{l}\text { Farm } \\
\text { population } \\
\text { ratio }\end{array}$} & $\begin{array}{l}\text { Peasant households } \\
\text { participating in farmland } \\
\text { transfer }\end{array}$ & 215 & 45 \\
\hline & $\begin{array}{l}\text { Peasant households not } \\
\text { participating in farmland } \\
\text { transfer }\end{array}$ & 263 & 59 \\
\hline \multirow[t]{2}{*}{$\begin{array}{l}\text { Contract land } \\
\text { area per capita }\end{array}$} & $\begin{array}{l}\text { Peasant households } \\
\text { participating in farmland } \\
\text { transfer }\end{array}$ & & - \\
\hline & $\begin{array}{l}\text { Peasant households not } \\
\text { participating in farmland } \\
\text { transfer }\end{array}$ & & - \\
\hline
\end{tabular}

c) Farmland transfer property rights strength evaluation indexes

Strength of farmland transfer property right means that peasant household's value judgment of land possessed during the transaction process is determined by size of the property rights to be transacted, namely "strength" of property rights to be transacted. Detailed evaluation indexes are shown below: (Table 4 Farmland transfer property rights strength evaluation indexes)
TABLE IV. FARMLAND TRANSFER PROPERTY RIGHTS STRENGTH EVALUATION INDEXES

\begin{tabular}{|c|c|c|c|}
\hline Index & State & $\begin{array}{l}\text { Sample } \\
\text { Number }\end{array}$ & $\begin{array}{l}\text { Ratio } \\
(\%)\end{array}$ \\
\hline \multirow{2}{*}{$\begin{array}{l}\text { Land is collectively } \\
\text { owned }\end{array}$} & Agree & 163 & 34 \\
\hline & Disagree & 315 & 66 \\
\hline \multirow{2}{*}{$\begin{array}{l}\text { Land contract } \\
\text { should be signed }\end{array}$} & Agree & 373 & 78 \\
\hline & Disagree & 105 & 22 \\
\hline \multirow{2}{*}{$\begin{array}{l}\text { Land contracting } \\
\text { right should be } \\
\text { permanent }\end{array}$} & Agree & 191 & 40 \\
\hline & Disagree & 287 & 60 \\
\hline \multirow{2}{*}{$\begin{array}{l}\text { Land can be } \\
\text { abandoned }\end{array}$} & Agree & 76 & 16 \\
\hline & Disagree & 411 & 84 \\
\hline
\end{tabular}

2) Method introduction

Through the analysis of 478 questionnaires, prices of farmland transfer of tested specimens are obtained, and on this basis peasant household's different endowment effects are judged.

Fundamentally, farmland transfer means to transfer the management right of the contracted land; based on this, all individuals including peasants may be either the buyer or the seller of land management right. The buyer and the seller will confirm the payable highest price P1 and the acceptable lowest price $\mathrm{P} 2$. The ratio of $\mathrm{P} 1$ and $\mathrm{Pc}$ is the value of peasant household's endowment effect.

$$
\mathrm{Y}=\mathrm{P} 2 / \mathrm{P} 1
$$

In case of $Y>1$, endowment effect exists, the larger value of $\mathrm{Y}$ is the stronger endowment effect is.

3) Test results

Land transfer prices are summarized based on 478 valid questionnaires and the value of corresponding endowment effect is figured out as shown in Table 5. 
TABLE V. SUMMARY SHEET OF FARMLAND TRANSFER ENDOWMENT EFFECT

\begin{tabular}{|c|c|c|c|c|c|}
\hline Index & Item & State & P1 & P2 & Y (Endowment Effect) \\
\hline \multirow{6}{*}{ Executive ability of farmland property rights } & \multirow{2}{*}{ To transfer farmland? } & Yes & 576 & 668 & 1.16 \\
\hline & & No & 1008 & 2469 & 2.45 \\
\hline & \multirow{2}{*}{ Purpose of farmland possession } & Self-use & 602 & 768 & 1.28 \\
\hline & & Sale & 1459 & 4876 & 3.34 \\
\hline & \multirow{2}{*}{ To abandon farmland? } & Yes & 418 & 5637 & 13.49 \\
\hline & & No & 889 & 1376 & 1.55 \\
\hline \multirow{6}{*}{$\begin{array}{l}\text { Resource } \\
\text { endowment }\end{array}$} & \multirow{2}{*}{ Agricultural income ratio } & $>40$ & 569 & 2113 & 3.71 \\
\hline & & $<40$ & 951 & 2628 & 2.76 \\
\hline & \multirow{2}{*}{ Farm population ratio } & $>40$ & 1050 & 2847 & 2.71 \\
\hline & & $<40$ & 579 & 784 & 1.35 \\
\hline & \multirow{2}{*}{ Contract area per capita (ha.) } & 0.16 & 995 & 1883 & 1.89 \\
\hline & & 0.13 & 668 & 2239 & 3.35 \\
\hline \multirow{6}{*}{ Legal and social identity } & \multirow{2}{*}{$\begin{array}{l}\text { Land } \\
\text { collective ownership }\end{array}$} & Agree & 1167 & 1666 & 1.43 \\
\hline & & Disagree & 585 & 991 & 1.69 \\
\hline & \multirow{2}{*}{ Signing of contract agreement } & Agree & 812 & 1849 & 2.28 \\
\hline & & Disagree & 607 & 979 & 1.61 \\
\hline & \multirow{2}{*}{ Permanent contracting right } & Agree & 1035 & 2999 & 2.90 \\
\hline & & Disagree & 598 & 1621 & 2.71 \\
\hline
\end{tabular}

Data statistical results in Table 5 show:

a) In case of endowment effect $Y>1$, peasants "cherish land" seriously and show weak willingness of farmland transfer.

Peasants prefer to overestimate the value of land management right during the transaction process and endow land with mysterious and unseparated feelings, which greatly weaken peasant's farmland transfer willingness.

b) Endowment effect of peasant households not participating in farmland transfer should be far higher than that of peasant households participating in farmland transfer

Peasant households not participating in farmland transfer refer to regard land as the foundation for the settlement of life and the source of survival, such survival dependence upon land is originated from both peasants' social instinct and accumulated social systems, and will ultimately restrain peasant's farmland transfer willingness.

c) Peasant households with a lower social recognition degree have a stronger endowment effect of farmland resources

Although land is collectively owned according to Chinese law, $66 \%$ of peasant households express no different opinions. They prefer to accept "land nationalization" which facilitates to improve authority and fairness of the property right of land in hands; moreover, most people's willingness of "noncollectively owned" farmland property right enhances the endowment effect and restrains peasant household's farmland transfer willingness. d) Clear property rights can stimulate peasant household's endowment effect

Explicit property rights determined according to law and household responsibility contracts can improve peasant household's ability to control land, and thus raise the resource endowment effect of land and suppress peasant's farmland transfer willingness.

\section{CONCLUSIONS}

No matter peasant households actually participate in farmland transfer or not, the endowment effect of resources

remains high and the endowment effect of peasant households not participating in farmland transfer is higher; besides, the higher the strength of property rights is, the stronger the endowment effect of resources is and the more easily peasant household's farmland transfer willingness will be restricted.

Contribution of land and agricultural income is positively correlated with the strength of peasant household's resource endowment effect, thus, we must improve peasant household's non-agricultural employability and non-agricultural employment income and minimize their survival dependence upon land so as to raise their farmland transfer willingness.

Strong complex of "cherishing land" and preference to the right of "reigning disposal" endow peasant households with obvious survival dependence as well as strong affection and personality dependence upon the land possessed, thus, the improvement of farmland transfer willingness is both an economic issue and a serious social psychological problem. 


\section{REFERENCES}

[1] Alchian A.: Some Economics of Property Rights, Politico, 1965(30):816-829.

[2] Radin,M.J: Property and Personhood. Stanford Law Review, 1982(34):1541-1580.
[3] Scott,J.: The Moral Economy of the Peasant. Yale University press, 1976.

[4] Luo Biliang. Contractual right of land: An Analysis of Peasant's Withdrawal Willingness and Influence Factors. Chinese Rural Economy, 2013 (06).

[5] Liu Zhiqiong. Endowment Effect, Fiscal Illusion and Public Policy. Journal of Nankai University (Social Sciences), 2011 (06). 